\title{
PENGGUNAAN BUKU CERITA GAMBAR BERSERI UNTUK MENINGKATKAN KEMAMPUAN MENYIMAK ANAK KELOMPOK B2 TK ASSALAAM KOTA TASIKMALAYA
}

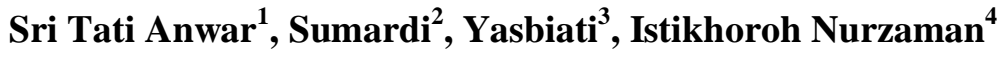 \\ ${ }^{1}$ TK Laboratorium Percontohan UPI Kampus Tasikmalaya \\ ${ }^{2}$ Program Studi PGPAUD UPI Kampus Tasikmalaya \\ ${ }^{3}$ Program Studi PGSD UPI Kampus Tasikmalaya \\ ${ }^{4}$ Program Studi PGSD UPI Kampus Tasikmalaya
}

Email: sritatianwar95@gmail.com

(Received: November 2018; Accepted: November 2018; Published: Desember 2018)

\begin{abstract}
This Classroom Action Research is motivated by the results of observations carried out in IP Assalam B2 Kindergarten group shows that the receptive language skills of children are still not achieved, especially in listening skills, for example there are still many children who have not paid close attention to learning, the researchers decided to conduct research using a serial picture story book. The book can cause great attraction for children and can also facilitate children's understanding. By reading a storybook with a serial image, the ability to listen to children will be well honed, children can interpret and retell what is in the story. This study aims to improve the ability of teachers to plan learning, implement learning and improve children's listening skills. The model used in this study is the Classroom Action Research (PTK) model with Suharsimi Arikunto model consisting of two cycles. Each cycle consists of planning, implementation, observation and reflection. Based on the results of the study showed an increase, this is evidenced by the increase in the ability of teachers in planning learning, the ability of teachers to carry out learning, the ability of teachers in carrying out learning using serial images and children's abilities in listening skills and other child development such as cognitive aspects, social emotional, physical motor, and religion. Obstacles faced by researchers when learning include the conditioning of children, appreciation in conveying stories and the use of descriptions of appropriate language for children.
\end{abstract}

Keywords: Listening,serial picture story book, Class B2

\begin{abstract}
ABSTRAK
Penelitian Tindakan Kelas ini dilatarbelakangi oleh hasil observasi yang dilaksanakan di kelompok B2 TK IP Assalam menunjukan belum tercapainya keterampilan reseptif anak khususnya pada kemampuan menyimak, contohnya masih banyak anak yang pada pembelajaran belum memerhatikan secara seksama, peneliti memutuskan untuk melakukan penelitian menggunakan buku cerita gambar berseri. Buku tersebut dapat menimbulkan daya tarik yang besar bagi anak juga dapat mempermudah pemahaman anak. Dengan cara membacakan buku cerita gambar berseri kemampuan menyimak anak akan terasah dengan baik, anak dapat menafsirkan dan menceritakan kembali apa yang ada dalam cerita tersebut. Penelitian ini bertujuan untuk meningkatkan kemampuan guru dalam merencanakan pembelajaran, melaksanakan pembelajaran dan meningkatkan kemampuan menyimak anak. Model yang digunakan dalam penelitian ini yaitu model Penelitian Tindakan Kelas (PTK) dengan model Suharsimi Arikunto yang terdiri dari dua siklus. Setiap siklus terdiri dari perencanaan, pelaksanaan, observasi serta refleksi. Berdasarkah hasil penelitian menunjukan adanya peningkatan, hal ini dibuktikan dengan meningkatnya kemampuan guru dalam merencanakan pembelajaran, kemampuan guru dalam melaksanakan pembelajaran, kemampuan guru dalam melaksanakan pembelajaran menggunakan buku cerita gambar berseri serta kemampuan anak dalam keterampilan menyimak serta perkembangan anak yang lain seperti aspek kognitif, sosial emosional, fisik motorik, dan agama. Hambatan yang dihadapi peneliti saat pembelajaran meliputi pengkondisian anak, penghayatan dalam menyampaikan cerita serta penggunaan uraian bahasa yang tepat untuk anak.
\end{abstract}

Kata Kunci : Menyimak, buku cerita gambar berseri, kelas B2 


\section{PENDAHULUAN}

Anak usia dini adalah sesosok individu yang sedang menjalani suatu proses perkembangan yang sangat melesat baik itu fisik ataupun mentalnya, anak dapat menangkap segala pembelajaran yang diberikan kepadanya dengan daya ingat yang kuat, perkembangan anak pada masa usia dini ini sangat berpengaruh bagi kehidupan dan pengetahuann yang akan dijalaninya dimasa mendatang.

Hal ini juga berbanding lurus dengan Peraturan Menteri Pendidikan dan Kebudayaan RI No. 146 Tahun 2014 Tentang Kurikulum 2013 Pendidikan Anak Usia Dini Lampiran 1 yaitu Kompetensi Dasar nomor 3.10 Memahami bahasa Reseptif (menyimak dan membaca) dan kompetensi dasar nomor 4.10 Menunjukan kemampuan Reseptif (menyimak dan membaca) dengan indikator untuk anak usia 5-6 tahun: anak mampu menceritakan kembali apa yang di dengar dengan kosakata yang lebih. Selain itu kemampuan menyimak yang harus dimiliki anak usia dini sebagaimana yang tercantum dalam Peraturan Menteri Pendidikan dan Kebudayaan No. 137 Tahun 2014 tentang Standar Nasional Pendidikan Anak Usia Dini mengenai standar isi tentang Standar Tingkat Pencapaian Perkembangan Anak (STPPA) untuk usia 5-6 tahun yaitu: 1. Mengerti beberapa perintah secara bersamaan; 2 . Mengulang kalimat yang lebih kompleks; 3. Memahami aturan dalam suatu permainan;.

Sebagaimana telah dijelaskan diatas bahwa dalam perkembangan bahasa yang bersifat reseptif, peneliti memfokuskan kajian skripsi perkembangan bahasa reseptif (menyimak dan membaca) ini berpusat pada perkembangan menyimak sesuai dengan hasil observasi permasalahan yang dilakukan di kelas B 2 TK IP Assalaam Kota Tasikmalaya.

Pada tahap pelaksanaan observasi yang dilakukan di kelas B 2 TK IP Assa* Kota Tasikmlaya mengenai kemam bahasa resptif ini, masih ada beb $\epsilon$, indikator pencapaian perkembangan yang dirasa kurang tercapai secara optimal, dalam kemampuan menyimak contohnya anak hanya memperhatikan pada saat guru menggunakan volume suara yang tinggi, dalam hal mendengarkan masih ada sebagian anak yang sering bermain dengan temannya, akibatnya mengganggu teman yang lain yang sedang mendengarkan, dalam hal menginterpretasikan, masih ada anak yang belum dapat menginterpretasikan sebuah cerita yang disampaikan oleh guru karena keterbatasan alat dalam menyampaikan cerita.

Berdasarkan permasalahan yang terjadi dan berbagai pertimbangan terkait kajiandari perkembangan bahasa reseptif ini, peneliti kemudian mengerucutkan menjadi kemampuan menyimak saja, kemampuan menyimak ini tidak sematamata mudah diperoleh oleh anak, kemampuan menyimak ini dapat diperoleh dalam pembelajaran, salah satunya dengan media buku cerita gambar berseri, buku cerita merupakan buku yang di dalamnya terdapat alur, tempat, dan tokoh serta pesan cerita yang di atur sedemikian rupa supa, gambar berseri merupakan "sejumlah gambar yang menggambarkan suasana yang sedang diceritakan dan menunjukan adanya kesinambungan antara gambar yang satu dengan gambar yang lainya (Rudi, 2013, hlm,72). Dengan menggunakan buku cerita gambar berseri sebagai alat untuk menyampaikan pembelajaran, anak mampu meningkatkan kemampuan imajinasi serta menyimak dengan baik dan tidak bosan dengan buku gambar yang bervariatif. Dengan meningkatnya kemampuan menyimak, akan berbanding lurus dengan kemampuan berbahasanya.

Berdasarkan latar belakang masalah diatas, peneliti melakukan Penelitian Tindakan Kelas (PTK) dengan judul "Penggunaan Buku Cerita Gambar Berseri untuk Meningkatkan Kemampuan Membaca Usia (Penelitian Tindakan Kelas pada Kelompok B 2 TK IP Assalaam Kota Tasikmalaya Tahun Ajaran 2017-2018)".

\section{TINJAUAN PUSTAKA}

\section{a. Pengertian Bahasa}

"Bahasa adalah salah satu bentuk komunikasi, entah itu tulisan, tertulis atau isyarat yang berdasarkan pada suatusistemdari simbolsimbol. Bahasa terdiri dari kata-kata yang digunakan oleh masyarakat beserta aturan- 
aturan untuk menyusun berbagai variasi dan mengkombinasikannya" (Santrock, 2007, hlm.353).

Menurut Vygotsky dalam (Walfok, 1995;Susanto, 2011, hlm.73) menyatakan bahwa "Language is critical for cognitive developmentt. Language provide a means for expressing ideas and asking question and it provides the categories and concept for thinking”. Bahasa merupakan alat untuk mengekpresikan ide dan bertanya, dan bahasa huga menghasilkan konsep dan kategorikategori untuk berpikir.

\section{b. Lingkup Perkembangan Bahasa}

Peraturan Menteri Pendidikan dan Kebudayaan Republik Indonesia Nomor 137 (2014, hlm. 27-28) menjelaskan tentang lingkup perkembangan bahasa anak usia dini. Lingkup perkembangan bahasa untuk anak usia 5-6 tahun yaitu sebagai berikut:

1. Memahami bahasa dengan standar tingkat pencapaian perkembangan anak yaitu:
a) Mengerti beberapa perintah secara bersamaan.
b) Mengulang kalimat yang lebih kompleks.
c) Memahami aturan dalam suatu permainan
d) Senang dan menghargai bacaan.

2. Mengungkapkan bahasa dengan standar tingkat pencapaian perkembangan anak yaitu:
a) Menjawab pertanyaan yang lebih kompleks.
b) Menyebutkan kelompok gambar yang memiliki bunyi yang sama.
c) Berkomunikasi secara lisan, memiliki pembendaharaan kata, serta mengenal simbol-simbol untuk persiapan membaca, menulis dan berhitung.
d) Menyusun kalimat sederhana dalam struktur lengkap (pokok kalimat- predikat-keterangan).
e) Memiliki lebih banyak kata-kata untuk mengekspresikan ide pada orang lain.
f) Melanjutkan sebagian cerita atau dongeng yang telah diperdengarkan.
g) Menunjukkan pemahaman konsep- konsep dalam buku cerita.

3. Keaksaraan dengan standar tingkat pencapaian perkembangan anak yaitu: a) Menyebutkan simbol-simbol huruf yang dikenal.

b) Mengenal suara huruf awal dari nama benda-benda yang ada di sekitarnya.

c) Menyebutkan kelompok gambar yang yang memiliki bunyi atau huruf awal yang sama.

d) Memahami hubungan antara bunyi dan bentuk huruf.

e) Membaca nama sendiri.

f) Menuliskan nama sendiri.

g) Memahami arti kata dalam cerita.

\section{c. Pengertian Menyimak}

Menyimak sebagai proses besar mendengarkan, mengenal, serta menginterpretasikan lambang-lambang lisan Andreson (dalam Tarigan, 2014. hlm.30). Menyimak bermakna mendengarkan dengan penuh pemahaman dan perhatian serta apresiasi Russel (dalam Tarigan, 2014. hlm. 30).

\section{d. Pengertian Buku Cerita Gambar Berseri}

Majid (2002, hlm. 8) mengemukakan bahwa "cerita merupakan salah satu bentuk sastra yang memiliki keindahan dan kenikmatan tersendiri. Akan menyenangkan bagi anakanak maupun orang dewasa, jika pengarang, pendongeng, dan penyimaknya sama-sama baik"

Sesuai penjelasan pengertian diatas, buku cerita gambar berseri dapat diartikan sebagai alat atau media yang digunakan oleh guru dalam proses pembelajaran berupa buku yang di dalamnya terdapat gambar dan mengandung cerita secara beruntut atau berseri.

\section{e. Langkah-langkah Penggunaan Buku Cerita Gambar Berseri}

Penggunaan buku ceria gambar berseri untuk meningkatkan kemampuan menyimak anak kelompok B 2 TK IP Assalaam adalah sebagai berikut:

1) Persiapan

a) Guru menyiapkan tempat/ruangan untuk bercerita.

Berserita sebaiknya dilaksanakan di ruangan yang tidak bising, dan tidak banyak aktivitas komunikasi. Ruangan kelas adalah salah satu tempat yang ideal karena di ruangan kelas anak sudah terbiasa menerima stimulasi pembelajaran.

b) Guru menyiapkan buku cerita gambar berseri. 
Dalam tahap menyiapkan buku cerita gambar berseri tentu yang harus ada adalah buku cerita bergambar yang sesuai dengan anak, baik dari segi penggunaan bahasa, pemilihan warna ataupun konten gambar yang ada didalam buku cerita.

c) Guru membaca terlebih dahulu buku cerita sebelum dibacakan di depan anak.

Sebelum dibaca di depan anak, guru terlebih dalahulu wajib paham dan membaca buku cerita bergambar, tujuannya supaya guru lebih mudah berimprovisasi dalam penyampaian buku cerita tersebut.

d) Guru mengondisikan anak.

Dalam mengkondisikan anak, sebaiknya guru melakukannya dengan permainan ataulagu-lagu yang dapat membuat anak fokus terhadap guru.

e) Guru melakukan apersepsi dan pembahasan tema.

Guru melaksaanakan penguatan dan pembahasan kembali mengenai tema yang kemarin dipeajari serta dihubungkan dengan tema yang akan dilaksanakan.

f) Guru menyampaikan tujuan kegiatan cerita yang akan dilaksanakan. Penyampaian tujuan dalam kegiatan bercerita berguna supaya anak memahami apa yang akan guru ceritakan.

g) Guru memotivasi dan menstimulasi anak untuk terlibat aktif dalam kegiatan bercerita.

Dalam menstimulasi anak supaya terlibat aktif dalam bercerita, guru memotivasi dengan kata-kata yang membuat anak menjadi semangat.

2) Teknis Penggunaan Buku Cerita Gambar Berseri

a) Guru mengkondidikan tempat duduk anak (posisi guru di depan anak, posisi anak dibuat menjadi setengah lingkaran).

Dalam pengkondisian tempat duduk ini, guru berada di depan anak dan anak dalam posisi setengah tingkaran, posisi seperti ini sangatlah ideal dan memberikan kesan langsung pada guru untuk bercerita. b) Guru menyampaikan tata tertib pada saat guru menyampaikan cerita.

Penyampaian tata tertib dalam pelaksanaan bercerita ini sangat penting dilakukan, walaupun dalam pelaksanaanya sering anak lupa akan tata tertib, tugas guru lah mengingatkan bahwa ada tata tertib yang disepakati di awal sebelum bercerita. Tata tertib ini meliputi: anak tidak berlarian ketika guru menyapaikan cerita; berkomunikasi apabila ada keperluan anak (BAK dan BAB); anak boleh menyampaikan pernyataanya terhadap cerita setelah diperkenankan oleh guru.

c) Guru menyampaikan identitas buku. Penyampaian identitas buku ini meliputi: penyampaian judul buku;pengarang buku; tokoh yang ada dalam buku; warna cover dll.

d) Guru memegang buku disamping kiri, arahkan fokus perhatian kepada anak anak.

Dalam penyampaian cerita, guru memegang buku disamping kiri, dan mengarahkan fokus perhatian kepada anak, tujuannya supaya guru tidak terhalangi oleh buku ketika menyampaikan cerita.

e) Guru membacakan cerita dengan tutur kata yang apik, dibuat lebih dramatis daripada tutur kata biasanya.

Penyampaian cerita hendaknya menggunakan tutur bahasa yang apik, artinya guru becerita dengan pelan-pelan, serta intonasinya desesuaikan dengan keadaan yang ada di dalam buku cerita.

f) Guru membuka halaman demi halaman dengan pelan dan jelas.

g) Sesekali, guru berhenti bercerita dan menanyakan komentar anak.

Tujuannya adalah mengetahui apakah anak masih fokus dalam mendengarkan dan menyimak cerita.

h) Guru memperhatikan anak dengan menjalin kontak mata dengan anak.

Menjalin kontak mata dengan anak dilakukan guna menegaskan alur dalam cerita, supaya anak dapat berimajinasi dengan bebas dan 
mempunyai kesan yang dalam terhdap cerita yang di bacakan oleh guru.

i) Guru menunjukan gambar dengan jelas kepada setiap anak.

Penunjukan gambar sangatlah penting, anak harus mengetahui dan melihat gambar, usahakan anak melihat dengan jelas gambar apa yang ada di dalam buku cerita tersebut, caranya dengan mendekatkan buku cerita tersebut secara perlahan-lahan kepada setian anak.

j) Diakhir cerita guru memberikan umpan balik berupa pertanyaanpertanyaan kepada setiap anak untuk mengetahui

sejauhmana perkembangan menyimak anak setelah dibacakan buku cerita gambar berseri.

\section{METODE}

Metode penelitian yang digunakan adalah Penelitian Tindakan Kelas atau Clasroom Action Research (CAR), penelitian ini menunjukan isi yang akan dibahas merupakan kegiatan penelitian yang akan dilaksanakan di dalam kelas (Dimyanti, 2013, hlm.112). "Raserch is about generating new knowledge. Action research creates new knowlwdgw based on enquiries conducted within specific and often practical contexts" penelitian adalah tentang menghasilkan pengetahuan baru.

Adapun model PTK yang digunakan adalah model PTK yang dikemukakan oleh Suharsimi Arikunto, menurut Arikunto (dalam Dimyanti, 2013, hlm.124) memberi penejelasan bahwa para ahli mengemukakan model penelitian tindakan pada garis besarnya terdapat empat tahapan yang lazim dilalui, yaitu, perencanaan, pelaksanaan, pengamatan/observasi, dan refleksi.

\section{a. Definisi Operasional Variabel Penelitian}

Pada setiap kegiatan penelitian, seorang peneliti harus menetapkan variabel yang akan dijadikan sebagai objek penelitiannya (Dimyanti, 2013, hlm.41). Variabel dalam penelitian ini yaitu:

1. Variabel

a) Variabel Proses

1) Aktivitas guru dalam melaksanakan pembelajaran dengan penggunaan buku cerita berseri untuk meningkatkan kemampaun menyimak anak kelompok B di TK Assalaam Kota Tasikmalaya.

Aktivitas guru meliputi perencanaan pelaksanaan pembelajaran, pelaksanaan pembelajaran dan evaluasi pembelajaran selama kegiatan dari awal sampai akhir. Cerita Gambar Berseri yang digunakan dalam pelaksanaan pembelajaran ini terdiri dari 3 Buku Cerita yang berisi gambar dengan konten yang sudah disesuaikan dengan anak usia dini. Buku Cerita Bergambar dengan seri yang terdiri dari buku yang berjudul (Aku Sayang Alloh, Aku Anak Jujur, dan Aku Belajar Puasa) lengkap dengan boneka tangan tokoh yang ada dalam buku cerita.

2) Aktivitas siswa dalam peningkatan kemampuan menyimak anak melalui penggunaan buku cerita gambar berseri di kelompok B2 TK Assalaam Kota Tasikmalaya.

Aktivitas kemampuan menyimak anak melalui penggunaan buku cerita gambar berseri meliputi lembar observasi: anak mendengarkan informasi yang disampaikan secara lisan, anak memahami isi dari cerita yang disampaikan dengan menjawab pertanyaan sederhana, anak menafsirkan isi dari cerita yang disampaikan, anak mengungkapkan pendapatnya tentang perilaku tokoh dalam cerita, dan memberikan reaksi yang tepat terhadap penyampaian cerita.

b) Variabel hasil

1) Peningkatan kemampuan guru dalam melaksanakan pembelajaran dalam penggunaan buku cerita berseri untuk meningkatkan kemampaun menyimak anak kelompok B2 di TK Assalaam Kota Tasikmalaya.

Peningkatan kemampuan guru meliputi: Rencana Pelaksanaan Pembelajaran Harian (RPPH/APKG I), lembar observasi Pelaksanaan Pembelajaran (APKG II), lembar observasi pelaksanaan pembelajaran menggunakan buku cerita gambar berseri, dan lembar observasi kemampuan bahasa menyimak (menyimak) anak kelompok B2 TK IP Assalaam.

2) Peningkatan kemampuan menyimak anak melalui penggunaan buku cerita gambar berseri di kelompok B2 TK Assalaam Kota Tasikmalaya.

Vaiabel hasil dari penelitian ini adalah meningkatnya kemampuan menyimak Anak Kelompok B2 TK Assalam Kota Tasikmalaya, 
dari skian teori yang sudah dipaparkan, hal ini selaras dengan Lampiran I Peraturan Mentri dan Kebudayaan Republik Indonesia Nomor 137 Tahun 2014 Tentang Standar Nasional Pendidikan Anak Usia Dini tentang Standar Isi Tingkat Pencapaian Perkembangan Anak, dalam lingkupan pengungkapan bahasa 5-6 Tahun, adalah :

a. Menjawab pertanyaan yang lebih kompleks

b. Menyebutkan kelompok gambar yang mempunyai bunyi yang sama

c. Berkomunikasi secara lisan, memiliki perbendaharaan kata, serta mengenal simbol-simbol untuk persiapan membaca, menulis dan berhitung

d. Menyusun kalimat sederhana dalam struktur lengkap (pokok kalimat-predikatketerangan)

e. Memiliki lebih banyak kata-kata untuk mengekpresikan ide pada orang lain

f. Melanjutkan sebagian cerita/dongeng yang telah diperdengarkan Menunjukkkan pemahaman konsep-konsep dalam buku cerita

\section{b. Teknik Analisis Data}

Analisi data yang digunakan pada penelitian ini adalah teknik deskriptif kualitatif dengan menggunakan presentase. Menurut tim peneliti proyek PGSM dalam (Muslich,2011, hlm.52) teknis analisis data dilakukan melalui tiga tahap, yaitu reduksi data, paparan data, dan penyimpulan.

Reduksi data adalah proses penyederhanaan data dengan cara memilih data yang diperoleh melalui pengamatan dnegan cara memilih data sesuai dengan kebutuhan penelitian. Dari pemilihan data tersebut, kemudian dipaparkan lebih sederhana menjadi paparan yang berurutan berupa paparan data dan akhirnya ditarik kesimpulan dalam bentuk pernyataan kalimat yang singkat dan padat, tetapi mengandung pengertian yang luas (Muslich,2011, hlm.25).

Selanjutnya (Sugiyono, 2013, hlm.337) "menggunakan analisis selama dilapangan model miles dan huberman, sebagai berikut :

1. Data Reduction (Reduksi Data)

Mereduksi data berarti merangkum, memilih hal-hal yang pokok, memfokuskan pada hal-hal yang penting, dicari tema dan polanya yang tidak perlu. Dengan demikian data yang direduksi akan memberikan gambaran yag lebih jelas, dan mempermudah peneliti untuk melakukan pengumpulan data selanjutnya, dan mencarinya bila diperlukan.

\section{Data Display (Penyajian Data)}

Setelah data direduksi, maka langkah selanjutnya adalah mendisplaykan data, data dapat dsajikan dalam bentuk tabel, grafik, phie chard, pictogram dan sejenisnya. "the most frequent from of display data qualitative reasech data in the past has been narrative tex", yang paling sering digunakan untuk menyajikan data dalam penelitian kualitatif adalah teks yang bersifat naratif (Huberman dalam Sugiyono, 2013, hlm.341)

3. Conclusin Drawing/verification

Langkah yang ketiga adalah penarikan kesimpulan dan verifikasi, kesimpukan awal yang dikemukakan masih bersifat sementara, dan akan berubah bila ditemukan bukti-bukti yang kuat yang mendukung pada tahap pengumpulan data berikutnya. Tetapi apabila kesimpulan yang dikemukakan pada tahap awal, didukung oleh bukti-bukti yang valid dan konsisten saat peneliti kembali kelapangan mengumpulkan data, maka kesimpulan yang dikemukakan merupakan kesimpulan yang kredibel".

Untuk mempermudah proses penelitian, peneliti juga menggunakan analisis kuantitaif untuk menyatakan sebuah predikat yang disesuaikan dengan asesment misal baik sekali, baik, cukup (Suharsimi Arikunto, 2013, hlm. 43) ini disesuaikan dengan asesmen yang ada di TK yaitu Belum Berkembang (BB), Mulai Berkembang (MB), Berkembang Sesuai Harapan (BSH), dan Berkembang Sangat Baik (BSB).

Data-data yang akan menentukan penelitian ini adalah sebagai berikut:

1. Rencana Pelaksanaan Pembelajaran Harian (RPPH), berisi tentang rencana yang tertuang dalam dokumentasi untuk merencanakan kegiatan pembelajaran.

2. Alat untuk mengukur kinerja guru dalam merencanakan dan melaksanakan pembelajaran yatu lembar observasi APKG I dan 2.

3. Alat untuk mengukur kinerja guru dalam melaksanakan pembelajaran menggunakan buku cerita gambar berseri yaitu lembar observasi kemampuan guru dalam melaksanakan pembelajaran melalui buku cerita gambar berseri. 
4. Alat untuk mengukur kemampuan menyimak anak yaitu lembar observasi kemampuan menyimak anak usia dini.

5. Data yang diperoleh kemudian di olah dan di evaluasi untuk mendapatkan hasil pembelajaran yang optimal.

Pengolahan dan penghitungan skor dalam penelitian ini sebagai berikut:

1. Lembar observasi guru (APKG I dan II)

\section{APKG I}

Rata-rata APKG I $=\frac{\text { Erata-rata aspek }(I+I I+I I I+I V)}{4}$

Persentase APKG I $=\frac{\text { Rata }- \text { rata yang diperoleh }}{\text { Rata-rata } \text { maksimal }}=\frac{\text { rata-rata yang diperoleh }}{4}$

\section{APKG II}

Rata-rata APKG II $=\frac{\sum \text { rata-rata aspek }(\mathrm{I}+\mathrm{II}+\mathrm{III})}{3}$

Persentase APKG II $=\frac{\text { Rata-rata yang diperoleh }}{\text { Rata-rata maksimal }}=$ $\underline{\text { rata-rata yang diperoleh }}$

2. Lembar observasi kemampuan guru dalam menggunakan buku cerita gambar berseri

Jumlah Skor Aspek: (R1+RII+RIII+RIV) =

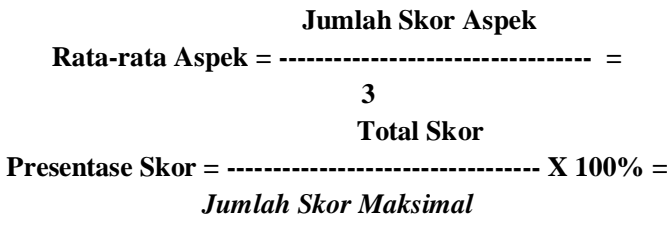

3. Lembar observasi kemampuan menyimak anak

Persentase per kriteria $=$

$\frac{\text { jumlah anak }}{\text { keseluruhan anak }} \times 100 \%$

$=\frac{\text { jumlah skor }}{13} \times 100 \%$

Kerangka pengolahan dan analisis data akan diberlakukan pada setiap siklus sampai perbaikan pembelajaran dianggap maksimal.

\section{c. Indikator Kinerja Keberhasilan}

Indikator kinerja kenberhasilan dalam penelitian ini merujuk pada rating-scale dimana data mentah yang diperoleh berupa angka kemudian ditafsirkan dalam pengertian kualitatif, rating-scale ini fleksibel, tidak terbatas pada pengukuran sikap saja, tetapi untuk mengukur persepsi responden terhadap fenomena lainnya, seperti skala untuk mengukur status sosial ekonomi, kelembagaan, pengetahuan, kemampuan, proses kegiatan, dan lain-lain (Sugiyono, 2012, hlm.141).

Untuk menyatakan keberhsilan guru dalam melaksanakan meningkatkan kemampuan bahasa menyimak (menyimak) anak kelompok B2 TK IP Assalam, maka taraf belajar keberhasilan belajar yang diambil peneliti sesuai dengan pendapat Djamah (dala Dewi, 2016), yaitu:

1. Apabila $75 \%$ dari anak didik yang mengikuti proses interaksi edukatif mencapai taraf keberhasilan minimal, optimal, atau bahkan maksimal, maka proses interaksi edukatif berikutnya dapat membahas pokok bahasan baru.

2. Apabila $75 \%$ atau lebih besar dari jumalah anak didik yang mengikuti proses interaksi edukatif mencapai taraf keberhasilan kurang (dibawah taraf minimal), maka proses interaksi edukatif berikutnya hendaknya bersifat perbaikan (remidial).

Taraf belajar keberhasilan belajar kemudian diadaptasi oleh peneliti melalui tabel sebagai berikut:

Tabel 3.4.

Taraf Belajar Keberhasilan

\begin{tabular}{llll}
\hline No & $\begin{array}{l}\text { Kriteria } \\
\text { Kesesuaian }\end{array}$ & Presnetase & Kategori \\
\hline 1 & $0-40$ & Kurang \\
\hline 2 & $41-73$ & Cukup \\
\hline 3 & $74-86$ & Baik \\
\hline 4 & $87-100$ & Baik Sekali \\
\hline
\end{tabular}

Dari tabel di atas, peneliti menentukan kinerja keberhasilan guru sebagai berikut:

1. Guru mengalami peningkatan kemampuan dalam merancang pembelajaran khususnya dalam perencanaan pembelajaran untuk meningkatkan kemampuan menyimak yang dikerucutkan menjadi kemampuan menyimak melalui buku cerita gambar berseri, sekurang-kurangnya menguasai $74 \%-86 \%$ dari indikator yang sudah ditetapkan.

2. Guru mengalami peningkatan kemampuan dalam melaksanakan pembelajaran khususnya dalam perencanaan pembelajaran untuk meningkatkan kemampuan menyimak yang dikerucutkan menjadi kemampuan menyimak melalui buku cerita gambar berseri, sekurangkurangnya menguasai $74 \%-86 \%$ dari indikator yang sudah ditetapkan. 
Untuk menyatakan keberhasilan anak, peneliti mengadopsi tabel kinerja keberhasilan dari suharsimi arikunto, sesuai dengan indikator yang dinyatakan peneliti yaitu:

\section{Tabel 3.5}

Presentase Keseuaian Anak

\begin{tabular}{|l|c|}
\hline \multicolumn{1}{|c|}{ Kriteria } & $\begin{array}{c}\text { Rentang } \\
\text { Presentase } \\
(\%)\end{array}$ \\
\hline $\begin{array}{l}\text { BB (Belum Berkembang): Jika mendapat } \\
\text { jumlah skor 0-5 }\end{array}$ & $0-25 \%$ \\
\hline $\begin{array}{l}\text { MB (Mulai Berkembang): Jika mendapat } \\
\text { jumlah skor 6-10 }\end{array}$ & $26-50 \%$ \\
\hline $\begin{array}{l}\text { BSH (Berkembang Sesuai Harapan: Jika } \\
\text { mendapat jumlah skor) 11-15 }\end{array}$ & $51-75 \%$ \\
\hline $\begin{array}{l}\text { BSB (Berkembang Sangat Baik): Jika } \\
\text { mendapat jumlah skor 16-20 }\end{array}$ & $76-100 \%$ \\
\hline
\end{tabular}

Berdasarkan tabel kriteria diatas, maka anak mengalami peningkatan kemampuan bahasa menyimak (menyimak) yaitu pada indikator mampu mendengarkan informasi yang disampaikan secara lisan, mampu memahami isi dari cerita yang disampaikan dengan menjawab pertanyaan sederhana, mampu menafsirkan isi dari cerita yang disampaikan, mampu mengungkapkan pendapatnya tentang perilaku tokoh dalam cerita, dan mampu memberikan reaksi yang tepat terhadap penyampaian cerita. Dimana sekurang-kurangnya mencapai 75\% (BSH).

Dari deskripsi diatas, dapat ditarik kesimpulan bahwa ada kriteria-kriteria yang harus ditingkatkan dalam penelitian ini, adalah kemampuan guru maupun anak khususnya dalam kemampuan bahasa menyimak (menyimak) melalui cerita gambar berseri.

\section{HASIL DAN PEMBAHASAN}

Penelitian yang telah dilakukan di TK IP Assalaam Kota Tasikmalaya adalah Penelitian Tindakan Kelas Kolaboratif yang terdiri dari dua siklus penelitian yaitu siklus I dan siklus II, berlangsung pada tanggal dari tanggal 18 April sampai 9 Mei 2018. Pelaksanaan siklus I beralngsung pada hari rabu, 19 april 2018 dengan tema alam semesta, sub tema bendabenda alam dan sub-sub tea benda cair (air), pelaksanaan siklus II berlangsung pada hari selasa tanggal 8 mei 2018 dengan tema diriku, sub tema agamaku, dan sub-sub tema belajar puasa. Penelitian tindakan kelas yang dilakukan di kelas B2 ini menggunakan buku cerita gambar berseri untuk meningkatkan kemampuan menyimak anak kelompok B2 TK IP Assalaam Kota Tasikmalaya. a. Perencanaan Pelaksanaan Pembelajaran

Dari data hasil penelitian Rencana Pelaksanaan Pembelajaran Harian (RPPH) pada siklus I mempunyai kekurangan yaitu pada alat-alat penilaian serta langkah-langkah pelaksanaan yang akan dilakukan. Kekurangan pada siklus I ini diperbaiki pada siklus ke II yaitu dengan memperbaiki alat penilaian serta merancang langkah kegiatan dengan rinci sesuai dengan fasilitas yang ada.

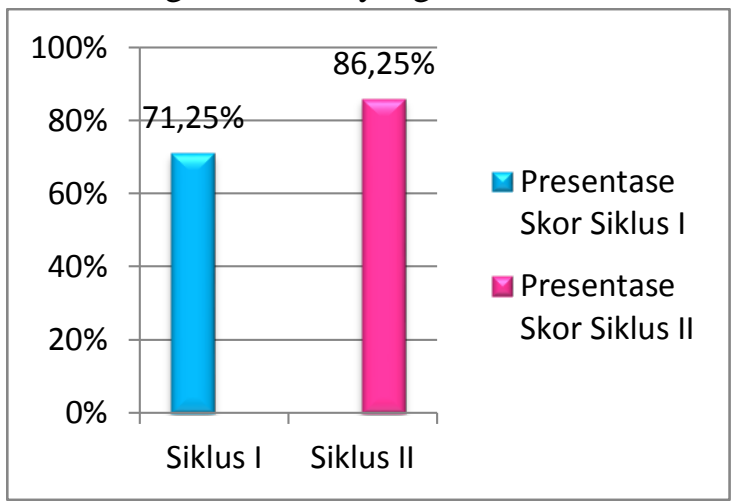

Perubahan Kemampuan Guru Kemampuan Guru dalam Merencanakan Pelaksanaan Pembelajaran (RPPH) Siklus I ke Siklus II

b. Pelaksanaan Pembelajaran Menggunakan Buku Cerita Gambar Berseri

Pelaksanaan pembelajaran menggunakan buku cerita gambar berseri untuk meningkatkan menyimak anak usia dini pada kelompok B2 di TK IP Assalaam, dari data hasil observasi pada siklus I masih terdapat kekurangan dalam beberapa aspek diantaranya Penggunaan 2 buku cerita gambar berseri membuat anak tebagi fokus, akibatnya ada anak yang kurang semangat mengikuti kegiatan pembelajaran, pengkondisian tempat untuk cerita menggunakan boneka tangan membuat guru kurang optimal dalam bercerita, pembagian porsi penggunaan boneka tangan dan buku cerita belum benar karena membuat guru kerepotan, Belum optimalnya kemampuan guru dalam melaksanakan pembiasaanpembiasaan pada awal pembelajaran, belum optimalnya kemampuan guru dalam melaksanakan komitmen kontrak belajar bersama anak. guru belum mampu mengkondisikan keadaan kelas dengan baik, dalam melakukan apersepsi, guru dirasa belum maksimal dalam menyampaikan pembahasan tema yang langsung berhubungan dengan cerita yang akan disampaikan, ketika sedang bercerita, guru kerepotan dengan penggunaan boneka tangan dan buku cerita secara bersamaan, pemberian motivasi yang kurang akibatnya perhatian anak terhadap guru 
menjadi kurang, guru belum optimal dalam penguasaaan setiap sudut kelas dalam pelaksanaan pembelajaran, guru harus lebih banyak memberikan penguatan kepada anak dalam pemberian pendapatnya, penanaman sikap juga harus ditingkatkan khususnya dalam mengantri untuk berbicara. Hal ini dapat diperbaiki dalam siklus ke II dengan perencanaan yang matang dalam penggunaan buku cerita gambar berseri dilengkapi dengan fasilitas yang ada di sekolah dan pengadaan fasilitas dari Leb.PAUD berupa panggung sandiwara, hal ini sangat membantu bagi pelaksanaan bercerita, melakukan pembiasaanpembiasaan berupa nyanyian, berbagai tepuk, mereview kegiatan yang sudah dilakukan, membaca surat-surat pendek dan apersepsi dari kegiatan pembuka ke kegiatan ini, kegiatan inti dilakukan dengan baik karena persiapan yang matang sebelummnya, guru sudah dapat memperkirakan apa saja yang diperlukan di dalam kelas, guru sudah menjelaskan tema dengan baik ini di tandai dengan benranya pertanyaan yang ditanyakan guru kepada anak contohnya apa sakja kegiatan yang telah dilakukan, menanyakan perasaan setelah melakukan kegiatan, tak lupa guru pun memotivasi anak dengan kata-kata semangat belajar, serta buku cerita sesuai tema dengan judul "Aku Belajara Puasa”, karakter boneka tangan, serta panggung sandiwara untuk menunjang penampilan ketika peneliti bercerita.

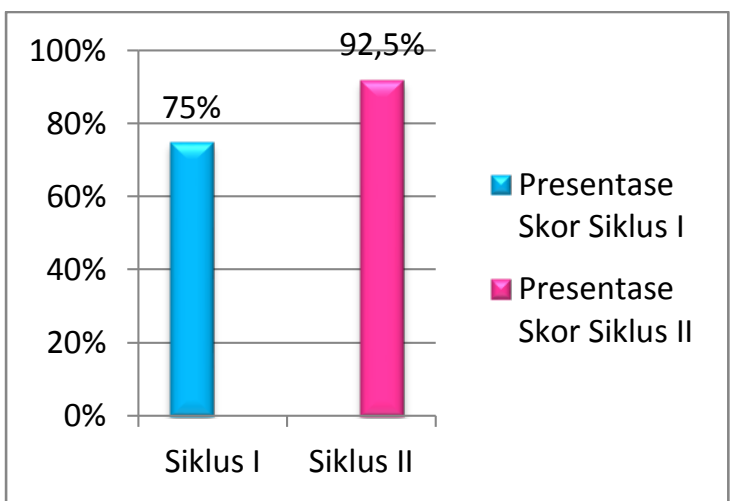

Peningkatan Kemampuan Guru dalam Pelaksanaan Pembelajaran

Melalui Penggunaan Buku Cerita Gambar Berseri Siklus I ke Siklus II

c. Peningkatan Kemampuan Menyimak Anak Usia Dini

Berdasarkan data hasil observasi kemampuan menyimak anak usia dini pada anak kelas B2 pada indikator anak mampu mendengarkan informasi yang disampaikan secara lisan sebanyak 4 orang anak atau $30,77 \%$ termasuk kedalam kriteria belum berkembang (BB), 7 orang anak atau 53,85\% termasuk kedalam kriteria mulai berkembang (MB), 2 orang anak atau 35,38\% termasuk kedalam kriteria berkembang sesuai harapan (BSH), dalam indikator ini belum ada anak yang termasuk kedalam kriteria berkembang sangat baik (BSB). Pada indikator anak memahami isi dari tema yang disampaikan dengan menjawab pertanyaan sederhana sebanyak 4 orang anak atau 30,77\% termasuk kedalam kriteria belum berkembang (BB), 8 orang anak atau 61,54 termasuk kedalam kriteria mulai berkembang (MB), 1 orang anak atau $7,69 \%$ termasuk kedalam kriteria berkembang sesuai harapam (BSH), dalam indikator ini belum ada anak yang termasuk kedalam kriteria berkembang sesuai harapan (BSH). Pada indikator anak menafsirkan isi dari tema yang disampaikan sebanyak 2 orang anak atau $15,38 \%$ anak termasuk kedalam kriteria belum berkembang (BB), 8 orang anak atau $61,54 \%$ termasuk kedalam kriteria mulai berkembang (MB), 3 orang anak atau 23,08\% termasuk kedalam kriteria berkembang sesuai harapan (BSH), dalam indikator ini belum ada anak yang termasuk kedalam kriteria berkembang sesuai harapan (BSH). Pada indikator anak mengungkapkan pendapatnya tentang kegiatan yang disampaikan sebanyak 4 orang anak atau 30,77\% termasuk kedalam kriteria belum berkembang (BB), 8 orang anak atau $61,54 \%$ termasuk kedalam kriteria mulai berkembang (MB), 1 orang anak atau 7,69\% termasuk kedalam kriteria berkembang sesuai harapan (BSH), dalam indikator ini belum ada anak yang termasuk kedalam kriteria berkembang sesuai harapan (BSH). Pada indikator memberikan reaksi yang tepat terhadap kegiatan yang telah disampaikan sebanyak 5 orang anak atau 38,46\% termasuk kedalam kriteria belum berkembang (BB), 8 orang anak atau $61,54 \%$ termasuk kedalam kriteria mulai berkembang (MB), dalam indikator ini belum ada anak yang termasuk kedalam kriteria berkembang sesuai harapan (BSH) dan berkembang sangat baik (BSB).

Berdasarkan pendapat tersebut dapat ditarik kesimpulan bahwa kemampuan menyimak merupakan pondasi awal dari keterampilan berbahasa. Dengan optimalnya perkembangan menyimak ini, akan bermanfaat pada kemampuan menyarap informasi yang disampaikan secara menyeluruh dan dapat meningkatkan kualitas berkomunikasi dengan 
orang lain. Dalam optimalisasi kemampuan menyimak pada anak usia dini harus sesuai dengan tahapan perkembangan anak diantaranya dapat menggunakan buku cerita gambar berseri dalam pelaksanaan pembelajarannya, metode yang digunakan dalam penyampaian buku cerita gambar berseri adalah egiatan bercerita, kegiatan bercerita ini sangat menyenangkan dan cocok diterapkan pada pembelajaran anak usia dini, untuk mengoptimalkan bercerita, guru dapat menggunakan jenis alat peraga berupa Read a Story Aloud Atory (Buku Cerita).

Peningkatan kemampuan menyimak anak usia dini melalui penggunaan buku cerita gambar berseri dilakukan sebanyak II siklus. Hasil observasi kemampuan menyimak anak pada siklus I mengalami peningkatan dibandingkan pada saat pra tindakan, diantaranya Kemampuan awal pada indikator mendengarkan informasi secara lisan ,kriteria Belum Berkembang (BB) sebesar 30,77\% atau sebanyak 4 orang anak, kriteria Mulai Berkembang (MB) sebesar 53,8\% atau sebanyak 7 orang anak, dan kriteria Berkembang Sesuai Harapan (BSH) sebesar $15,38 \%$ atau sebanyak 2 orang anak, pada indikator ini belum ada anak yang mencapai kriteria Berkembang Sesuai Harapan (BSH). Sedangkan pada siklus I tidak ada satu orang anak pun yanag termasuk kedalam kriteria Belum Berkembang (BB), kriteria Mulai Berkembang (MB) sebesar $30,77 \%$ atau sebanyak 4 orang anak, kriteria Berkembang Sesuai Harapan (BSH) sebesar 69,23\% atau sebanyak 9 orang anak, pada indikator ini belum ada anak yang termasuk ke dalam kriteria Berkembnag Sangat Baik (BSB). Kemampuan awal pada indikator memahami isi dari cerita yang disampaikan, dengan menjawab pertanyaan kriteria Belum Berkembang (BB) sebesar $30,77 \%$ atau sebanyak 4 orang anak, kriteria Mulai Berkembang (MB) sebesar $61,54 \%$ atau sebanyak 8 orang anak, dan kriteria Berkembang Sesuai Harapan (BSH) sebesar $7,69 \%$ atau sebanyak 1 orang anak, pada indikator ini belum ada anak yang mencapai kriteria Berkembang Sesuai Harapan (BSH). Sedangkan pada siklus I tidak ada satu orang anak pun yanag termasuk kedalam kriteria Belum Berkembang (BB), kriteria Mulai Berkembang (MB) sebesar $15,38 \%$ atau sebanyak 2 orang anak, kriteria Berkembang
Sesuai Harapan (BSH) sebesar 76,92\% atau sebanyak 10 orang anak, kriteria Berkembnag Sangat Baik (BSB) sebesar 7,69 atau sebanyak 1 orang anak. Kemampuan awal pada indikator menafsirkan isi dari cerita yang disampaikan, kriteria Belum Berkembang (BB) sebesar 15,38\% atau sebanyak 2 orang anak, kriteria Mulai Berkembang (MB) sebesar $61,54 \%$ atau sebanyak 8 orang anak, dan kriteria Berkembang Sesuai Harapan (BSH) sebesar 23,08\% atau sebanyak 3 orang anak, pada indikator ini belum ada anak yang mencapai kriteria Berkembang Sesuai Harapan (BSH). Sedangkan pada siklus I kriteria tidak ada satu orang anak pun yanag termasuk kedalam kriteria Belum Berkembang (BB), kriteria Mulai Berkembang (MB) sebesar 46,25\% atau sebanyak 6 orang anak, kriteria Berkembang Sesuai Harapan (BSH) sebesar $38,46 \%$ atau sebanyak 5 orang anak, kriteria Berkembnag Sangat Baik (BSB) sebesar $15,38 \%$ atau sebanyak 2 orang anak. Kemampuan awal pada indikator mengungkapkan pendapatnya tentang perilaku tokoh dalam cerita, kriteria Belum Berkembang (BB) sebesar $30,77 \%$ atau sebanyak 4 orang anak, kriteria Mulai Berkembang (MB) sebesar $61,54 \%$ atau sebanyak 8 orang anak, dan kriteria Berkembang Sesuai Harapan (BSH) sebesar 7,69\% atau sebanyak 1 orang anak, pada indikator ini belum ada anak yang mencapai kriteria Berkembang Sesuai Harapan (BSH). Sedangkan pada siklus I tidak ada satu orang anak pun yanag termasuk kedalam kriteria Belum Berkembang (BB), kriteria Mulai Berkembang (MB) sebesar 46,25\% atau sebanyak 6 orang anak, kriteria Berkembang Sesuai Harapan (BSH) sebesar 53,84\% atau sebanyak 7 orang anak, pada indikator ini belum ada anak yang termasuk ke dalam kriteria Berkembnag Sangat Baik (BSB). Kemampuan awal pada indikator memberikan reaksi yang tepat terhadap penyampaian cerita, tidak ada satu orang anak pun yang termasuk ke dalam kriteria Belum Berkembang (BB), kriteria Mulai Berkembang (MB) sebesar $38,46 \%$ atau sebanyak 5 orang anak, dan kriteria Berkembang Sesuai Harapan (BSH) sebesar $61,54 \%$ atau sebanyak 8 orang anak, pada indikator ini belum ada anak yang mencapai kriteria Berkembang Sesuai Harapan (BSH). Sedangkan pada siklus I tidak ada satu orang anak pun yanag termasuk kedalam 
kriteria Belum Berkembang (BB), kriteria Mulai Berkembang (MB) sebesar 38,46\% atau sebanyak 5 orang anak, kriteria Berkembang Sesuai Harapan (BSH) sebesar 61,54\% atau sebanyak 8 orang anak, pada indikator ini belum ada anak yang termasuk ke dalam kriteria Berkembnag Sangat Baik (BSB).

Hasil observasi pada siklus II menunjukan bahwa kemampuan menyimak (menyimak) anak mengalami peningkatan yang sangat baik Kemampuan awal pada indikator indikator mendengarkan informasi secara lisan tidak ada satu orang anak pun yanag termasuk kedalam kriteria Belum Berkembang (BB) dan Mulai Berkembang (MB), kriteria Berkembang Sesuai Harapan (BSH) sebesar 76,92\% atau sebanyak 10 orang anak, Berkembnag Sangat Baik (BSB) sebesar $23,07 \%$ atau sebanyak 3 orang anak. Kemampuan awal pada indikator memahami isi dari cerita yang disampaikan dengan menjawab pertanyaan sederhana tidak ada satu orang anak pun yanag termasuk kedalam kriteria Belum Berkembang (BB), kriteria Mulai Berkembang (MB), kriteria Berkembang Sesuai Harapan (BSH) sebesar $15,39 \%$ atau sebanyak 2 orang anak, Berkembnag Sangat Baik (BSB) sebesar $84,61 \%$ atau sebanyak 11 orang anak. Pada indikator menafsirkan isi dari cerita yang disampaikan tidak ada satu orang anak pun yanag termasuk kedalam kriteria Belum Berkembang (BB), kriteria Mulai Berkembang (MB), kriteria Berkembang Sesuai Harapan (BSH) sebesar $61,53 \%$ atau sebanyak 8 orang anak, Berkembnag Sangat Baik (BSB) sebesar $38,46 \%$ atau sebanyak 5 orang anak. Pada indikator mengungkapkan pendapatnya tentang perilaku tokoh dalam cerita tidak ada satu orang anak pun yanag termasuk kedalam kriteria Belum Berkembang (BB), kriteria Mulai Berkembang (MB), kriteria Berkembang Sesuai Harapan (BSH) sebesar $61,53 \%$ atau sebanyak 8 orang anak, Berkembnag Sangat Baik (BSB) sebesar $38,46 \%$ atau sebanyak 5 orang anak. Pada memberikan reaksi yang tepat terhadap penyampaian cerita tidak ada satu orang anak pun yanag termasuk kedalam kriteria Belum Berkembang (BB), kriteria Mulai Berkembang (MB), kriteria Berkembang Sesuai Harapan (BSH) sebesar 38,46\% atau sebanyak 5 orang anak, Berkembnag Sangat Baik (BSB) sebesar $61,53 \%$ atau sebanyak 8 orang anak.

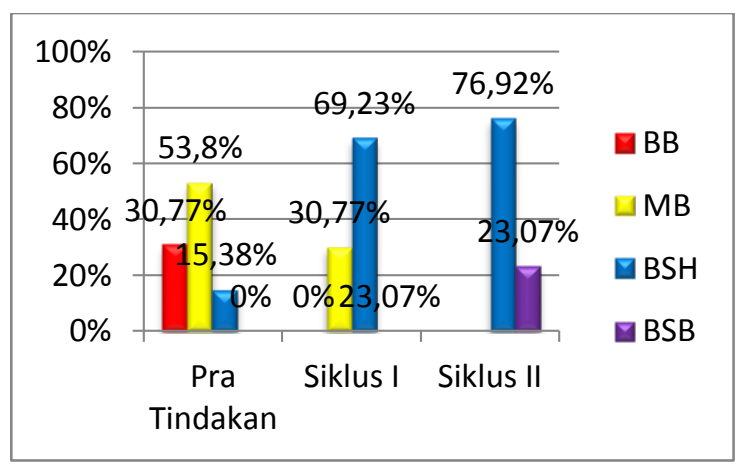

Diagram Peningkatan Kemampuan Menyimak Pada Indikator Anak Mendengarkan Informasi yang Disampaikan Secara Lisan

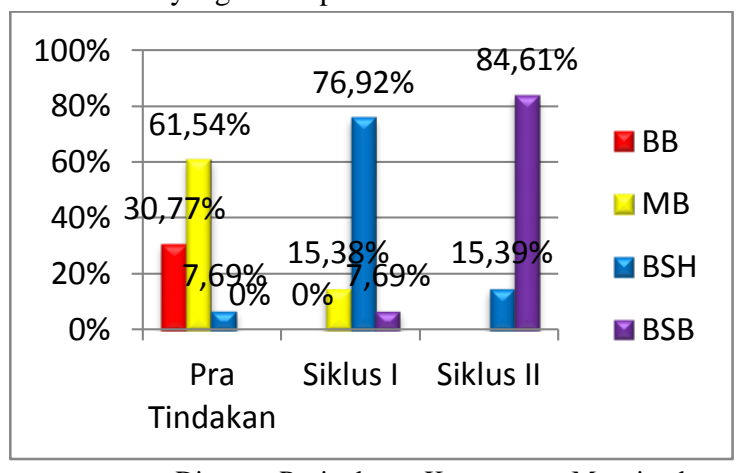

Diagram Peningkatan Kemampuan Menyimak Anak Memahami Isi dari Cerita yang Disampaikan dengan Menjawab Pertanyaan Sederhana

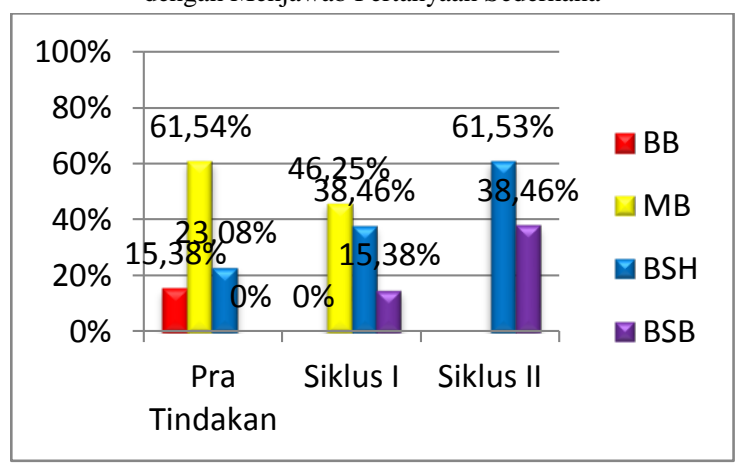

Diagram Peningkatan Kemampuan Menyimak Anak Menafsirkan Isi dari Cerita yang Disampaikan Perubahan Kemampuan Awal ke Siklus I

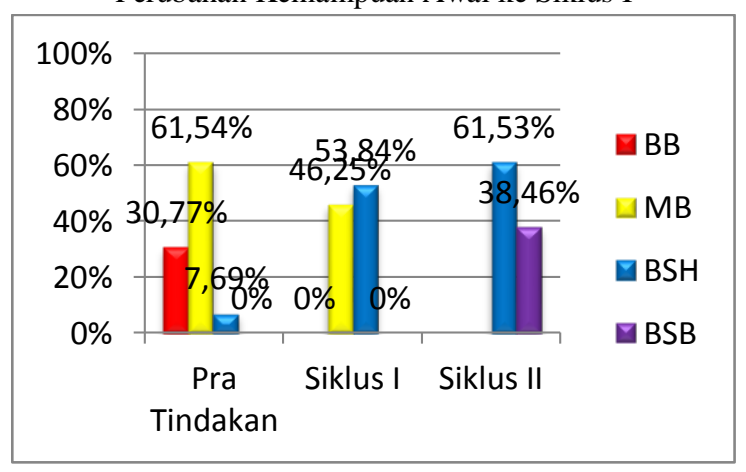

Diagram Peningkatan Kemampuan Menyimak Anak Mengungkapkan Pendapatnya Tentang Perilaku Tokoh dalam Cerita

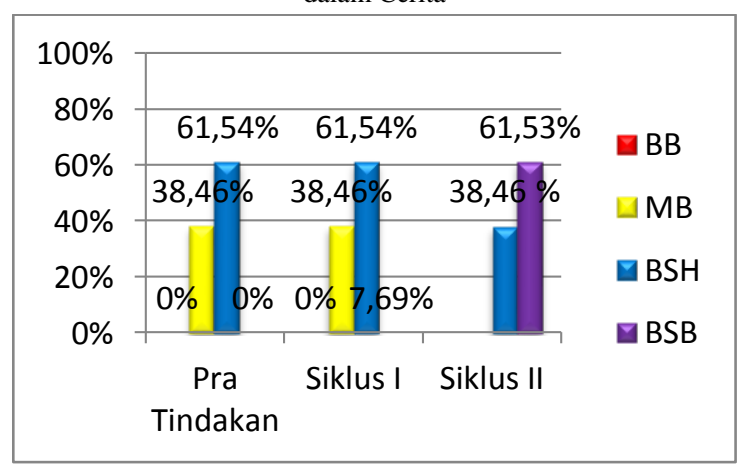


Diagram Peningkatan Kemampuan Menyimak Memberikan Reaksi yang Tepat Terhadap Penyampaian Cerita

Kemampuan menyimak anak usia dini mengalami peningkatan pada setiap siklusnya, peningkatan tersebut dapat dikatakan karena penggunaan buku cerita gambar berseri dalam proses pembelajaran sudah bejalan dengan baik.

Melalui buku cerita gambar berseri anak belajar menyimak yang bersifat menerima pada bagian menyimak, anak dapat mendengarkan informasi secara lisan, memahami isi dari cerita yang disampaikan dengan menjawab pertanyaan sederhana, menafsirkan isi dari cerita yang disampaikan, mengungkapkan pendapatnya tentang perilaku tokoh dalam cerita, dan memberikan reaksi yang tepatterhadap penyampaian cerita.

Secara umum keseluruhan aspek kinerja guru dan kemampuan menyimak (menyimak) anak dari siklus I dan II sudah dapat dikatakan berhasil walaupun belum mencapai kriteria sempurna. Pada penelitian tindakan kelas siklus ke II, fokus tindakan menitik beratkan pada kinerja keberhasilan kemampuan menyimak (menyimak) anak dengan menggunakan buku cerita gambar berseri yang terdiri dari perencanaan pembelajaran harian (RPPH), pelaksanaan pembelajaran, pelaksanaan pembelajaran harian menggunakan cerita gambar berseri serta kemampuan menyimak anak dianggap telah mencapai titik optimal. Dengan landasan tersebut, penelitian di hentikan sampai siklus II karena hasil penelitian sudah mencapai kriteria keberhasilan yang telah ditentukan.

Dengan demikian dapat disimpulkan bahwa buku cerita gambar berseri dapat meningkatkan kemampuan menyimak anak usia dini pada kelompok B2 TK IP Assalaam Kota Tasikmalaya.

\section{KESIMPULAN}

Perencanaan pembelajaran dengan menggunakan buku cerita gambar berseri untuk meningkatkan kemampuan cerita gambar berseri pada anak kelompok B2 TK IP Assalaam Kota Tasikmalaya Kota Tasikmalaya disusun berdasarkan kajian teori dan merujuk pada kriteria keberhasilan yang ditetapkan. Peneliti menyusun Rencan Pelaksanaan Pembelajaran Harian (RPPH) yang digunankan sebagai acuan pelaksanaan pembelajaran. Untuk menyempurnakan proses pembelajaran, peneliti juga menyusun lembar observasi kemampuan guru dalam merencanakan pembelajaran, kemampuan guru dalam melaksanakan pembelajaran, kemampuan guru dalam melaksanakan pembelajaran menggunankan buku cerita gambar berseri serta lembar observasi anak. Kemampuan guru dalam merencanakan pelaksanaan pembelajaran dengan dengan menggunakan buku cerita gambar berseri untuk meningkatkan kemampuan menyimak anak usia dini mengalami peningkatan pada setiap siklusnya, peningkatan ini tidak terlepas dari refleksi serta perbaikan demi perbaikan yang telah dilakukan.

Pelaksanaan pembelajaran dengan menggunakan buku cerita gambar berseri untuk meningkatkan kemampuan menyimak anak usia dini pada kelompok 2 TK IP Assalaam kota tasikmalaya pada hakikatnya dapat meningkatkan kemampuan guru dalam melaksanakan pembelajaran pada setiap siklsunya, eningkatan ini tidak terlepas dari refleksi serta perbaikan demi perbaikan yang telah dilakukan.

\section{SARAN}

Dalam melaksanakan perencanaan pembelajaran untuk meningkatkan kemampuan menyimak anak usia dini sebaiknya guru mempunayi kaidah-kaidah pelaksanaan yang disesuaikan dengan kurikulum serta keadaan lingkungan sekolah, dengan perencanaan yang sempurna maka akan tercipta proses pembelajaran yang bermutu.

Bagi peneliti yang selanjutnya akan melakukan penelitian yang bekonsentrasi tentang peningkatan kemampuan menyimak anak usia dini melalui buku cerita gambar berseri supaya dapat memerhatikan setiap gagasan pokok mendalam dan inovasi yang beragam supaya terciptanya proses pembelajaran yang efektif. Dengan terciptanya proses pembelajaran yang efektif akan menumbuhkan rasa semangat dan memotivasi anak mengikuti pembelajaran dengan menyenangkan serta outputnya adalah meningkatnya kemampuan menyimak anak usia dini.

\section{DAFTAR PUSTAKA}

Amini. (2016). Meningkatkan Kemampuan Keaksaraan Reseptif Anak Melalui Permainan Pola Suku Kata di Taman Kanak-kanak Negeri Pembina Yogyakarta. Juranal: jurnal 
7. 12362-30747-1-PB OK, 675. doi:https://journal.uny.ac.id $>$ jpa $>$ do wnload

Arikunto, S. (2013). Prosedur Penelitian: Suatu Pendekatan Praktik. Jakarta: PT Rineka Cipta

Arikunto, S. (2010). Prosedur Penelitian: Suatu Pendekatan Praktik. Jakarta: PT Rineka Cipta

Burns, A. (1999). Collaborative Ation Reaserch for Englis Language Teachers. Unitid Kingdom 40 West 20th, New York, Ny 10011-4L11. USA : Cambridge University Press 199

Dimyanti, J.M.M (2013). Metode Penelitian Pendidikan dan Pelaksanaan pada Pendidikan Anak Usia Dini (PAUD).Jakarta : Kencana Prenadamedia Group

Direktorat Jendral Pendidikan Anak Usia Dini dan Pendidikan Masyarakat Kementrian Pendidikan dan Kebudayaan Republik Indonesia. (2013). Kerangka Dasar dan Struktur Kurikulum 2013 Pendidikan Anak Usia Dini. Jakarta : Kemendikbud

Madyawati, L. (2016). Strategi Perkembangan Bahasa pada Anak. Jakarta: Kencana

Muslih, M. (2011). Melaksanakan Penelitian Tindakan Kelas Itu Mudah.Jakarta: Bumi Aksara

Hartono, R. (2013). Ragam Mengajar yang Mudah Diterima Murid. Jogjakarta : Diva Press

J.Beaty, J. (2013). Observasi Perkembangan Anak Usia Dini. Jakarta : Kencana
Kusumah, W. (2010). Mengenal Penelitian Tindakan Kelas. Jakarta : PT Indeks

Koshy, V. (2005). Action Research for Improving Practice. London : A SAGE Publication Company

Kwok Y.L. dkk. (2015). Research in Autism Spectrum Disorders. Journal : Meta-analysis of receptive and expressive language skills in autism spectrum disorder, 207. doi: http://ees.elsevier.com/RASD/defaul t.asp

Otto, B. (2015). Perkembangan Bahasa Pada Anak Usia Dini. Jakarta : Kencana

Pancaningrum, N. (2015). Pengenalan Baca Tulis Bagi Anak Usia Dini. Jurnal : Vol. 3 No. 2, 12-13. doi: journal.stainkudus.ac.id $>$ dowmload $>$ pdf

Peraturan Menteri Pendidikan dan Kebudayaan Republik Indonesia. (2014). Lampiran I Peraturan Menteri Pendidikan dan Kebudayaan Republik Indonesia Nomor 137 Tahun 2014 Tentang Standar Nasional Pendidikan Anak Usia Dini. Jakarta : Kemendikbud

Peraturan Menteri Pendidikan dan Kebudayaan Republik Indonesia. (2014). Lampiran I Peraturan Menteri Pendidikan dan Kebudayaan Republik Indonesia Nomor 146 Tahun 2014 Tentang Kurikulum 2013 Pendidikan Anak Usia Dini. Jakarta : Kemendikbud

Rahmat, A. Mamonto. (2016). Pengaruh Metode Bercerita Terhadap Kemampuan Menyimak Anak di Kota Selatan Gorontalo. Journal Of Nonformal Education and Community Empowererment. doi: http//jourmal.unnes.ac.id/sju/index.p $\mathrm{hp} / \mathrm{jnfc}$ 
Ribeiro, Abranides, Dkk. (2016). Receptive Language and Intellectual Abilities In Preterm Children. Brazil : Cross Mark, doi: http://doi.org/10.1016/j.earlhumdev. 2016.03.011

Singer, R. (2018). Language \& Communication. Journal : A smal apeech community with many small languages: The role of receptive multilingualism in supporting linguistic deversity at warruwi community. 12. doi: www. Elsevier. Com/locate/langcom.

Subana, M. Sunarti. (2011). Strategi Belajar Mengajar Bahasa Indonesia Sebagai Pendekatan, Metode Teknik, dan Media Pengajaran. Bandung : Pustaka Setia

Subyakto, (2005). Upaya Meningkatkan Kemampuan Menyimak Anak Usia Dini. Jakarta : Depdiknas

Sugiyono, Y. N (2012). Metode Penelitian Pendidikan. Bandung: Alfabeta

Sugiyono, Y.N. (2013). Konsep Dasar Pendidikan Anak Usia Dini. Jakarta: PT Indeks

Sukardi. (2014). Metodologi Penelitian Pendidikan. Jakarta : PT Bumi Aksara

Susanto, A. (2011). Perkembangan Anak Usia Dini. Jakarta :Kencana

Tarigan, H. G (2014). Menyimak Sebagai Suatu Keterampilan Berbahasa. Bandung : Angkasa

Tehupeiory, M. Suwasta, W. Dkk.

Penerapan Metode Bercerita Menggunakan Media Gambar untuk Mengingkatkan Kemampuan Bahasa Anak Kelompok B Semseter II. Singaraja. Jurnal : e-Journal PGPAUD Universitas Pendidikan Ganesa Jurusan Pendidikan Anak
Usia Dini (Volume 2 No 1

Tahun2014).doi:http://download.port algaruda.org/article.php?article $=304$ $190 \& \mathrm{val}=1341 \&$ title $=$ ENERAP $\% 20$ METODE\%20BERCERITA\%20\%2 OMENGGUNAKAN20\%MEDIA\%2 0GAMBAR\%20UNTUK\%20MENI NGKATKAN\%20KEMAMPUAN\% 20BERBAHASA\%20ANAK\%20KE LOMPOK\%20B\%20SEMESTER\% 20II\%20TAHUN\%20PELAJARAN \%202013/2014\%20DI\%20TK\%20K EMALA\%20BAHAYANGKARI\%2 02\%SINGARAJA

Wiriatmadja, R. (2009). Metode Penelitian Tindakan Kelas.Bandung : PT Remaja Rosdakarya 